\title{
Parameterisation of gypsum mortar for alternative structural consolidation of traditional floors
}

\author{
Fernando Vegas, Camilla Mileto, Valentina Cristini, José Ramón Ruiz-Checa \\ Instituto de Restauración del Patrimonio, IRP, Universitat Politècnica de València, UPV, Valencia, Spain \\ Email address: \\ fvegas@cpa.upv.es (F. Vegas), cami2@cpa.upv.es (C. Mileto), vacri@cpa.upv.es (V. Cristini), joruiche@cpa.upv.es (J. R. Ruiz-Checa)
}

\section{To cite this article:}

Fernando Vegas, Camilla Mileto, Valentina Cristini, José Ramón Ruiz-Checa, Parameterisation of Gypsum Mortar for Alternative Structural Consolidation of Traditional Floors. Advances in Materials. Vol. 2, No. 4, 2013, pp. 48-52. doi: 10.11648/j.am.20130204.11

\begin{abstract}
The role of gypsum as a construction material in vernacular architecture, not only as an auxiliary material, but also for enhancing structural features in floors and even in pillars, has had a long-standing history of application in different traditional buildings in some parts of Spain. The authors have identified the main properties of this material from a structural point of view by experimenting in situ on traditional gypsum jack arch floors as part of the project "Structural consolidation of traditional floors with compression layers of gypsum with fibres" (UPV/PAID-05-11/2893). Several traditional and commercial compression layers for traditional floors were made with different proportions of water in the mixture to parameterise its use and achieve the ideal thickness and dosage. In this research, the authors have used both traditional dosages and experimental mixtures containing fibres, which were monitored by standard tests of surface hardness and resistance to compression and flexion. This work presents the main results of the properties of the different types gypsum obtained in the laboratory analysis phase as an alternative option for the structural reinforcement of traditional floors.
\end{abstract}

Keywords: Structural Gypsum, Dosification, Performance, Mechanical Tests at Laboratory

\section{Introduction}

Until the first half of the twentieth century, before the wide-spread use of concrete structures, gypsum mortar played a crucial structural role in the construction of traditional jack arch floors, especially in the eastern half of the Iberian Peninsula. It is in this area where gypsum is plentiful, especially in the basins of the Ebro and Andalusian rivers [1]. This structural use has extended in some areas even to structural pillars, in order to provide protection from atmospheric agents and prevent capillary moisture rising from the ground through the combined use of sockets, eaves and copings, among others.

Within the framework of this building tradition, the authors have carried out a research project, which analyses the performance of the gypsum mortar employed in historic floors, focusing on the specificity of its construction characteristics and application. Meanwhile, this data has been updated and supplemented by a study, which attempts to improve and parameterise these historic solutions, carrying out a number of laboratory experiments.

\section{Background and Preliminary Experiments}

The project includes some preliminary initiatives, carried out since 2008, mainly related to the study and documentation of gypsum mortar as a traditional material in vernacular architecture, from the firing of raw materials using pre-industrial kilns, to its preparation and application in the building site [2]. Furthermore, a chemical analysis of samples taken from structural pillars and other building systems has been done, in order to try to establish not only the characterisation of the raw material itself, but also the water used in its preparation [3]. This component doubtlessly plays a significant role during the process of mixing it with water, primarily in light of its mechanical performance. [4].

In accordance with local tradition, masonry works are normally dosed with a water/gypsum mortar ratio of $1: 1$ in order to plaster walls. This ratio is reduced for bonding the inner partition walls reaching values of $0.6-0.8: 1$. This ratio is further minimised for structural elements such as pillars or floors to $0.4-0.5: 1$. Based on these premises and taking into consideration the amount of water during the preparation phase, in 2011 [5], the first of a series of laboratory studies 
was carried out with different test specimens (40 x 40 x 160 $\mathrm{mm})$ manufactured with commercial gypsum and mixed with several amounts of water (i.e. $0.3 ; 0.4,0.5,0.6,0.8$ ), tested in accordance with UNE-EN 13279-2 [6]. The results in this case have been very satisfactory, taking into consideration that with a very modest water/gypsum mortar ratio of $0.3: 1$ up to $30 \mathrm{MPa}$ (compressive strength) was achieved. This value decreased to $16 \mathrm{MPa}$ with a greater water dosage amount of $0.5: 1$. Finally, with a water/gypsum mortar ratio of $0.8: 1,6 \mathrm{MPa}$ was achieved.

In recent years, not only laboratory studies but also practical experiments on in situ reinforcements have been carried out, thanks to studies on different traditional floors. Researches were carried out on traditional jack arch floors made with wooden joists and gypsum vaulting. Several reinforcements have been done using gypsum mortar compression layers made with different water-binder ratios, to which were also added different types of fibres (organic and/or polymeric). The final objective has been to overcome, through the use of gypsum and fibres, issues such as excess of weight, stiffness, moisture, incompatibilities and transpirability which occur with other materials commonly used for these constructive solutions, such as cement.

\section{Experimental Consolidation Project}

Preliminary results based on different experiments carried out both in the laboratory as well as in pilot projects have established that gypsum mortar may possess satisfactory mechanical performance.

To achieve this, the project presented below proposes the consolidation of several traditional jack arch floors with wooden $\log$ joists and gypsum vaulting with reinforced gypsum compression layers. The place of study has been a small vernacular construction site in the region of Rincón de Ademuz, Valencia, Spain, where gypsum has been used for structural pillars as well as for the different jack arch floors. [7].

\subsection{Sample Preparation and Dosage}

One of bases for this project has been not only to establish the optimum water/gypsum mortar ratio during the preparation, as previously explained in the preceding chapter, but also to examine the mechanical performance of the gypsum upon addition of different types of fibres.

In this way 13 different dosifications were examined, prepared in situ and carried out. Three test specimens with standardised dimensions (160 x $40 \times 40 \mathrm{~mm})$ and a cylinder of $300 \mathrm{~mm}$ in height and $150 \mathrm{~mm}$ in diameter [UNE-EN 13279-2] were made from each of them. Different types of gypsum were employed for the manufacture of the samples [8] (a reddish artisan gypsum called Albarracín, YG/L controlled-setting gypsum, YG fast-setting gypsum and dental use gypsum (Alamo brand). To each sample was also added different types of fibre (natural cork from cork oak to lighten the mixture, or lamb's wool, straw, PBO fibres, fibreglass, esparto grass) in order to test various types of reinforcements).

\subsection{Gypsum Employed: Characterisation}

Traditional gypsum used in construction (hemihydrate gypsum) is obtained by partial dehydration of natural gypsum stone $\left(\mathrm{CaSO}_{4} \cdot 2 \mathrm{H}_{2} \mathrm{O}\right)$, subjected to low heat $\left(120-150^{\circ}\right)$ at atmospheric pressures or with slight depression. On the basis of kiln conditions as well as treatment times and grinding, different allotropic hemihydrate gypsum mortar varieties may be obtained $\left(\mathrm{CaSO}_{4} \cdot 1 / 2 \mathrm{H}_{2} \mathrm{O}\right)$, respectively or $\beta$ [9].

Type $\alpha$, more compact than type $\beta$, has a smoother appearance, shiny with thicker crystals and faster setting in addition to having mechanical strength properties 10 times greater than variety $\beta$, which is characterised by more uniform crystals and a spongy appearance.

These varieties also have products known as setting retarders, divided based on the retardation mechanism. Controlled setting of gypsum is possible due to the presence of electrolytes in the mixture (which reduce the solubility of the gypsum) or through substances that modify the crystalline structure of the gypsum (primarily carbonates) or with high-molecular-weight organic compounds (which act as protector colloids [10]).

Specifically, for this research, samples were made with YG/L (controlled-setting gypsum) (samples 1-2). Furthermore, YG/L mixture samples were obtained (controlled-setting gypsum) with YG (quick-setting thick gypsum) (samples 6-7-8 and 11-12-13) [8]. The artisan gypsum employed in the research is known as red gypsum or "salmon coloured", originating from the region of Albarracín, (Aragón- Spain). It is called that due to the high level of impurities it contains, which give it its characteristic chromaticism (samples 3, 4 and 5), which reflects the geological nature of the region. Its most significant characteristic is the use of two varieties of gypsum stone for its manufacture, one grey and the other red, both fired at the same time, giving this gypsum its peculiar reddish tone.

The dark grey stone has magnesium-rich clays and the other stone, red in colour, has iron-rich clays. Moreover, the two stones have silica impurities, both amorphous and crystalline. This artisan method of manufacturing results in a finished product with exceptional binding capacity, making it suitable for use in outdoor environments [11-12].

This particular property of this gypsum is due not only to the raw material employed but also to its artisan production method. Thus, during the firing phase, a corbelling dome is formed on sandstone supports inside the kiln and the gypsum is dehydrated through a continuous process lasting about 18 hours. The red stones, in smaller numbers than the grey stones, are placed in places where the fire takes longer to reach them, the iron oxide present acting as a catalyst that lowers the phase transition point. [11].

Finally, during the experiment, a calcium sulphate hemihydrate gypsum, especially suitable for the manufacture of collage molds for industrial tile has been 
employed as a final binder, which is characterized by its high hardness and controlled expansion (samples 9-10).

\subsection{Testing}

The different samples manufactured in situ have been transferred to the laboratory of the Department of Architectural Construction (ETSIE/UPV) (Valencia - Spain), where all test specimens have been subjected to several mechanical tests: Shore C surface hardness test, flexion test, compression and characterisation of the Young's modulus [11]. Specifically, a test was carried out to determine Shore C surface hardness (using the Ibertest hardness tester, carrying out testing on 8 points for each test specimen: standardised prismatics of $160 \times 40 \times 40 \mathrm{~mm}$ and standardised cylinders of $300 \times 150 \mathrm{~mm}$ ). Flexion tests were also carried out (on three standardised test specimens of 160 x 40 × $40 \mathrm{~mm}$ obtained from each of the 13 established dosifications at a test speed of $0.05 \mathrm{kN} / \mathrm{sec}$.). Compression tests were also carried out (on six standardised prismatic test specimens of $40 \times 40 \mathrm{~mm}$ obtained from the 13 established dosifications [Standard UNE EN 13279-2].

The mechanical characterisation concluded with an elastic analysis of test specimens manufactured from the different dosifications. In order to determine the elasticity module (Young's modulus), standardised cylindrical test specimens of $300 \times 150 \mathrm{~mm}$ were employed (one for each of the established dosifications, based on the values of rupture during compression at a test speed in all cases of $3 \mathrm{kN} / \mathrm{s}$ ). Ibertest instrumentation was employed for testing. In order to determine surface hardness, a Shore C sclerometer was used; for flexion tests, a model PEF-150-HDA press; and finally for compression and elasticity, a model MEH-1500 SW press (table 1).

Table 1. Flexion, Compression, Ultimate Tensile Strength Results

\begin{tabular}{c|ccccc}
\hline & \multicolumn{2}{c}{ Flexion } & & \multicolumn{2}{c}{ Compression } \\
\hline Samples & $\mathbf{F}(\mathbf{K N})$ & $\mathbf{v}(\mathbf{K N} / \mathbf{s})$ & $\mathbf{T}(\mathbf{M P a})$ & $\mathbf{F}(\mathbf{K N})$ & $\mathbf{T}(\mathbf{M P a})$ \\
\hline $\mathrm{n}^{\circ} 1$ & 2.33 & 0.05 & 5.46 & 25.55 & 15.97 \\
\hline $\mathrm{n}^{\circ} 2$ & 1.9 & 1 & 4.462 & 22.60 & 14.13 \\
\hline $\mathrm{n}^{\circ} 3$ & 0.48 & 0.05 & 1.13 & 4.39 & 2.74 \\
\hline $\mathrm{n}^{\circ} 4$ & 0.37 & 0.05 & 0.87 & 2.16 & 1.35 \\
\hline $\mathrm{n}^{\circ} 5$ & 0.44 & 0.05 & 1.03 & 4.32 & 2.71 \\
\hline $\mathrm{n}^{\circ} 6$ & 1.22 & 0.05 & 2.86 & 13.42 & 8.39 \\
\hline $\mathrm{n}^{\circ} 7$ & 1.47 & 0.05 & 3.48 & 33.17 & 20.37 \\
\hline $\mathrm{n}^{\circ} 8$ & 1.18 & 0.05 & 2.77 & 12.52 & 7.89 \\
\hline $\mathrm{n}^{\circ} 9$ & 1.70 & 0.05 & 3.98 & 19.62 & 12.16 \\
\hline $\mathrm{n}^{\circ} 10$ & 3.40 & 0.05 & 8 & 54.35 & 33.96 \\
\hline $\mathrm{n}^{\circ} 11$ & 1.36 & 0.05 & 3.45 & 21.12 & 16.35 \\
\hline $\mathrm{n}^{\circ} 12$ & 1.90 & 0.05 & 4.45 & 13.00 & 8.12 \\
\hline $\mathrm{n}^{\circ} 13$ & 1.42 & 0.05 & 3.34 & 14.38 & 8.99 \\
\hline & & & & & \\
\hline
\end{tabular}

\subsection{Results}

As indicated at the beginning of this report, the prepared samples are intended to be enhancements for traditional vernacular flooring, specifically as a compression layer.

In this way, after completion of laboratory work the following results were obtained; differentiated based on the different tests carried out, resumed below (graphic 1).

Taking into consideration the resulting average flexion strength for the 13 dosifications tested (3.45 MPa), it has been determined that this is exceeded by the values obtained in sample 7 (lamb's wool 30\% lamb's wool YG/L-YG gypsum), sample 11 (lamb's wool $30 \%$ and mixture of YG/L-YG gypsum) and sample 12 (straw and mixture of YG/L-YG gypsum) at 3.48 MPa, 3.45 $\mathrm{MPa}$ and 4.45 $\mathrm{MPa}$, respectively.

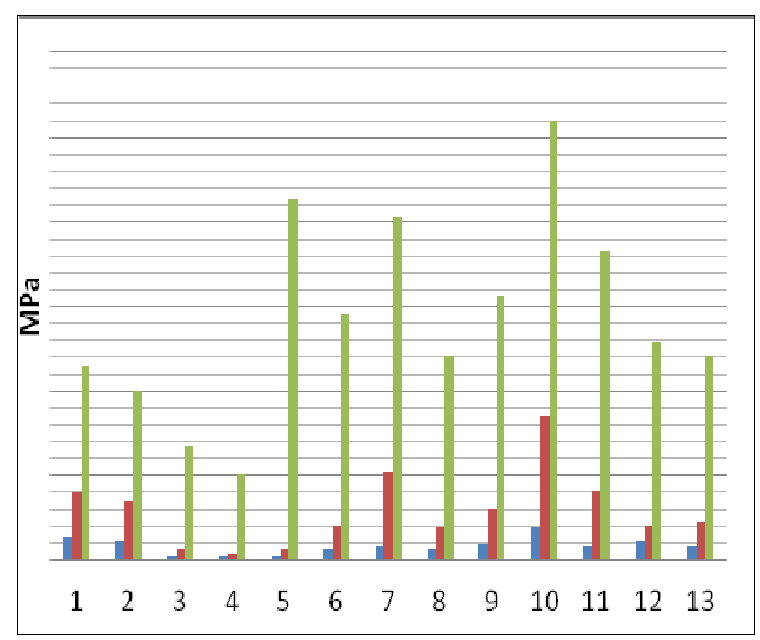

Graphic 1. Flexion (Blue), Compression (Red) And Young's Modulus (Green) Tests For The 13 Samples Analysed.

\begin{tabular}{ccc}
\hline \multicolumn{3}{c}{ Ultimate Tensile Strength } \\
\hline $\mathbf{v ( K N / s )}$ & Y. Modulus (MPa) & Ultimate Tensile Strength (MPa) \\
3 & 4592.2 & $10.27(\mathrm{v} 4.25 \mathrm{KN} / \mathrm{s})$ \\
3 & 4014.2 & $6.85(\mathrm{v} 3 \mathrm{KN} / \mathrm{s})$ \\
3 & 2724.20 & $2.04(\mathrm{v} 4.25 \mathrm{KN} / \mathrm{s})$ \\
3 & 2021.2 & $0.93(\mathrm{v} 1 \mathrm{KN} / \mathrm{s})$ \\
3 & 8558.1 & $13.25(\mathrm{v} 5 \mathrm{KN} / \mathrm{s})$ \\
3 & 5825.3 & $6.14(\mathrm{v} 5 \mathrm{KN} / \mathrm{s})$ \\
3 & 8121.8 & $12.15(\mathrm{v} 5 \mathrm{KN} / \mathrm{s})$ \\
3 & 4838.3 & $4.31(\mathrm{v} 5 \mathrm{KN} / \mathrm{s})$ \\
3 & 6247.1 & $8.68(5 \mathrm{KN} / \mathrm{s})$ \\
3 & 10.418 & $30.51(\mathrm{v} 5 \mathrm{KN} / \mathrm{s})$ \\
3 & 7327.9 & $2.07(\mathrm{v} 5 \mathrm{KN} / \mathrm{s})$ \\
3 & 5138.2 & $6.29(\mathrm{v} 5 \mathrm{KN} / \mathrm{s})$ \\
3 & 4806.8 & $6.95(\mathrm{v} 5 \mathrm{KN} / \mathrm{s})$ \\
\hline
\end{tabular}




\section{Conclusions}

With respect to compression test results, the resulting average compression strength for the 13 dosifications tested $(11.78 \mathrm{MPa})$ is exceeded by the values obtained in sample 7 (lamb's wool 30\% lamb's wool YG/L-YG gypsum), sample 11 (lamb's wool 30\% and mixture of YG/L-YG gypsum) and sample 12 (straw and mixture of $\mathrm{YG} / \mathrm{L}-\mathrm{YG}$ gypsum) at 20.37 MPa and 16.35 MPa, respectively.

With respect to the resulting average value of the elasticity modules (Young's modulus) for the 13 dosifications tested $(5,741.02 \mathrm{MPa})$, this is exceeded by the values obtained in sample 5 (PBO- p-phenylene-2,6 benzobisoxazole, cork and mixture of $\mathrm{YG} / \mathrm{L}-\mathrm{YG}$ gypsum), sample 6 (lamb's wool 20\%, cork and mixture of YG/L-YG gypsum), sample 7 (lamb's wool $30 \%$ and mixture of YG/L-YG gypsum) and sample 11 (lamb's wool 30\% and mixture of $\mathrm{YG} / \mathrm{L}-\mathrm{YG}$ gypsum), at $8,558.1 \mathrm{MPa}, 5,825.3$ $\mathrm{MPa}, 8,121.8 \mathrm{MPa}$ and 7,327.9 $\mathrm{MPa}$, respectively.

In terms of surface hardness [14], samples of Alamo gypsum mortar with wool have shown the best results (table 2).

Table 2. Hardness Tests Results

\begin{tabular}{cccc}
\hline \multicolumn{3}{c}{ Hardness Values } \\
\hline Samples & Values & Samples & Values \\
$\mathbf{n}^{\circ} \mathbf{1}$ & $89-90$ & $\mathbf{n}^{\circ} \mathbf{2}$ & $84-85$ \\
$\mathbf{n}^{\circ} \mathbf{3}$ & $66-67$ & $\mathbf{n}^{\circ} \mathbf{4}$ & $64-65$ \\
$\mathbf{n}^{\circ} \mathbf{5}$ & $63-64$ & $\mathbf{n}^{\circ} \mathbf{6}$ & $86-87$ \\
$\mathbf{n}^{\circ} \mathbf{7}$ & $94-95$ & $\mathbf{n}^{\circ} \mathbf{8}$ & $90-91$ \\
$\mathbf{n}^{\circ} \mathbf{9}$ & $93-94$ & $\mathbf{n}^{\circ} \mathbf{1 0}$ & $98-99$ \\
$\mathbf{n}^{\circ} \mathbf{1 1}$ & $95-96$ & $\mathbf{n}^{\circ} \mathbf{1 2}$ & $85-87$ \\
$\mathbf{n}^{\circ} \mathbf{1 3}$ & $84-85$ & & \\
\hline
\end{tabular}

Consequently, based on this experiment, it may be concluded that the addition of natural fibres, particularly wool, provides considerable improvement to compression layers in terms of mechanical behaviour.

While it is certain that PBO Poly fibres (p-phenylene-2,6-benzobisoxazole fig.1) or Alamo gypsum (fig.2) offer better results, it should be noted that these products increase the cost for these dosifications.

Contrary, wool provides significant improvement, particularly in terms of compression and elasticity. Furthermore, this material is $100 \%$ ecological and whose cost is significantly lower than that of the artificial fibres previously indicated.
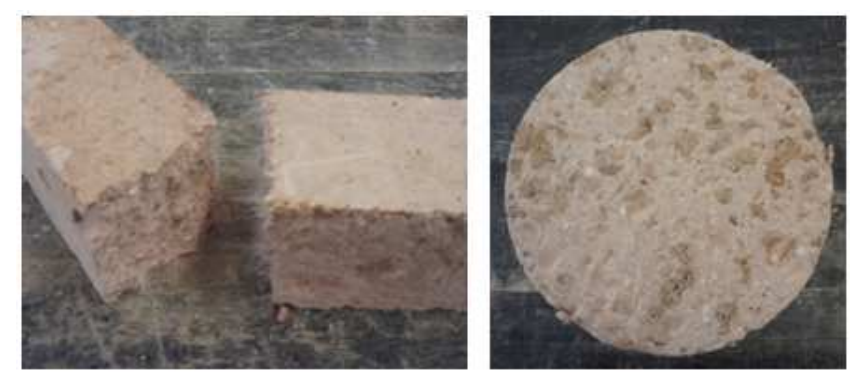

Fig.1. Samples $N^{\circ} .5$, With PBO Fibres + Cork +Red Gypsum Mortar
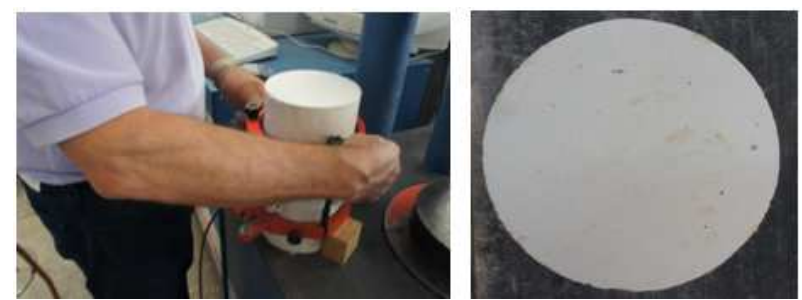

Fig.2. Samples $N^{\circ}$.10, With Alamo Gypsum

\section{References}

[1] Garate Rojas I., Artes de los yesos, yeserías y estucos, Munilla-Lería Ed., Madrid, 2007

[2] Mileto C., Vegas F. \& Guimaraens G., Homo faber, Arquitectura pre-industrial en el Rincón de Ademuz, Mancomunidad del Rincón de Ademuz Ed-, Casas Altas, 2008

[3] Bianco A. \& Guerrisi G. "La arquitectura tradicional a examen: Diagnóstico experimental en la comarca del Rincón de Ademuz",, in Loggia, Arquitectura \& Restauración, num. 17, UPV Ed.,Valencia, 2005

[4] Vegas F.; Mileto C., Fratini F. \& Rescic S., "May a building stand upon gypsum structural walls and pillars? The use of masonry made of gypsum in traditional architecture in Spain". In Proceeding of the Eight International Masonry, edited by W. Jäger, B. Haseltine and A. Fried, MSTU Ed., Dresden, 2010, pp.2183-2192

[5] Vegas F.; Mileto C.; Ivorra S. \& Baeza, F.J., "Checking Gypsum as Structural Material". Applied Mechanics and Materials nº117-119, 2012, pp.1576-1579

[6] UNE-ENE 13279-282006 Gypsum Binder and gypsum plaster. Part 2: tests methos

[7] Vegas F., Mileto C., Renovar Conservando. Manual de restauración de la arquitectura rural del rincón de Ademúz, Mancomunidad del Rincón de Ademuz Ed., Casas Altas, 2007

[8] UNE 102010/86 Yesos de construcción.

[9] Wirshing F., "Sulfato de calcio", in Ullmann's Encyclopedia of industrial chemistry, VCH Ed., Weinheim, 1985

[10] Villanueva Domínguez, L.: "Evolución histórica de la construcción con yeso", in Informes de la Construcción. Especial yesos, Instituto Torroja, vol. 56, nº493, CSIC Ed, Madrid, septiembre/octubre 2004, pp. 5-11

[11] Sanz D., De Villanueva L., "Albarracín y el yeso rojo, 
(Albarracín and the red gypsum)", in Informes de la Construcción, Vol. 56, n ${ }^{\circ}$ 493, CSIC Ed., Madrid, 2004

[12] Sanz Zaragoza, J.M., "Actuaciones sobre el patrimoniofortificado de la provincia de Teruel". In Actas de las III Jornadas de Castellología Aragonesa. Zaragoza: ARCA Ed., 2008, pp.95-114
[13] Roso i García R.,Liiçons de Guixos, UPV,Valencia, 2008

[14] Ihom P., "Hardness improvement of $\mathrm{Pb} 75 \%$ - Sb15\% Sn $10 \%$ bearing alloy through reinforcement with $5 \% \mathrm{v} / \mathrm{v}$ $\mathrm{SiO} 2$ particulates", Journal of Material Sciences n² Usak University , 2012, pp. 205-212 